\title{
Spatial distribution of atmospheric pollutants through biomonitoring in tree bark using X-Ray fluorescence
}

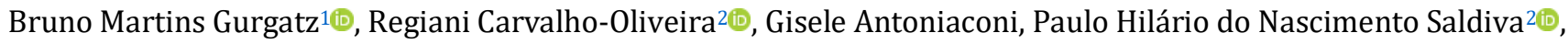 \\ Luciano Fernandes Huergo'1(D, Rodrigo Arantes Reis ${ }^{1+[i]}$
}

${ }^{1}$ Federal University of Paraná - Litoral, 512 Jaguariaíva St, Matinhos, Paraná, Brazil

2 Medical School of São Paulo University (FMUSP), 455 Dr. Arnaldo Av, Cerqueira César, São Paulo

+ Corresponding author: Rodrigo Arantes Reis, phone: +55 51 3717-7545, e-mail address: reisra@gmail.com

\section{ARTICLE INFO}

Article history:

Received: January 28, 2018

Accepted: July 4, 2018

Published: August 23, 2018
Keywords:

1. air pollution

2. biomonitoring

3. harbor

4. fertilizer

ABSTRACT: Several studies have shown that tree barks can absorb air contaminants, therefore, trees can be used as biomonitors to identify the distribution of atmospheric pollutants. The city of Paranaguá, located at the coast of the Paraná State in Brazil, hosts the largest bulk cargo port in Latin America and an elevated number of fertilizer processing industries. In this study we used tree barks coupled to $\mathrm{X}$-ray fluorescence spectrometer analysis to biomonitor the distribution of air pollutants in the city of Paranaguá. We identified correlation between the levels of the elements $\mathrm{K}$ and $\mathrm{Cl}$, with high levels detected near fertilizer warehouses. High levels of Fe were detected near railways and train stations. The low levels of $\mathrm{Zn}, \mathrm{Al}$, $\mathrm{Ba}$ and $\mathrm{Mg}$ detected in a traffic restricted zone confirmed that these elements are good indicators of vehicles traffic and validate our experimental approach of using tree barks for air pollution biomonitoring.

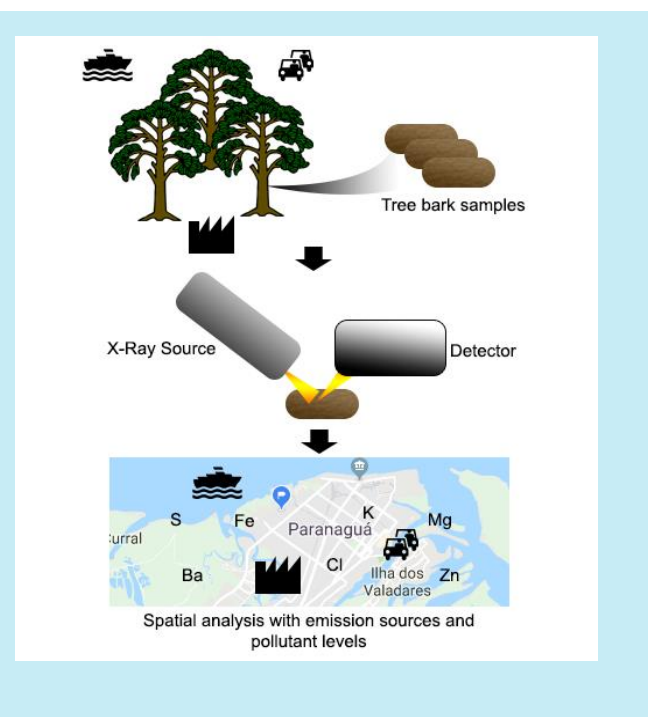

\section{Introduction}

It is estimated that air pollution-related diseases killed seven million people in 2012 worldwide, and air pollution it is known to be the single largest environmental risk today ${ }^{1}$. In Latin America, approximately 35,000 people die annually because of air pollution. The air pollution is the result of urbanization and industrialization processes along with a heavy dependence on fossil fuels and ${ }^{2,3}$.

Traditional methods for monitoring air quality are generally time consuming and expensive, an alternative method for air quality surveys is the use of living organisms, a process known as biomonitoring. A biomonitor is an organism that accumulates pollutants in its tissues, acting as a sampler of pollutants ${ }^{4}$. Several studies have shown that tree barks can absorb air contaminants. Hence, trees can be used as biomonitors to identify the distribution of atmospheric pollutants ${ }^{5-7}$. In Brazil, studies have validated the use of tree barks as air biomonitor for urban traffic ${ }^{5}$, industrial activities ${ }^{8}$ and environmental injustice assessment ${ }^{9}$.

The operation of ports relay on the use of several equipments contribute to air pollution including ships, trucks, and train engines ${ }^{10}$. Diesel 
is widely used in port activities and is directly related to asthma, rhinitis, and the development of cancer $^{11-13}$. A recent study has estimated the annual environmental costs of the Port of Kaohsiung in Taiwan at approximately 123 million dollars ${ }^{14}$.

The city of Paranaguá, located at the coast of the Paraná State in Brazil, hosts the largest bulk cargo port in Latin America. Most of the soybean produced in Brazil is exported at the Paranaguá port, this port is also a stream for the import of fertilizers that supply Brazilian crops. The Paranaguá port also attends demands of other general cargo and chemical products ${ }^{15}$. The transport of goods in and out the port is achieved mostly by the use of heavy trucks and by a railway service. The city of Paranaguá also hosts a number of fertilizer processing industries. The portuary and industry activities are the main sources of atmospheric pollution that can negatively impact in human health in the region. In this study we used tree barks coupled to X-ray fluorescence spectrometer analysis to biomonitor the distribution of air pollutants in the city of Paranaguá.

\section{Experimental}

A map of the Paranaguá city is depicted in Figure 1. The map shows the location of the port, major roads, railway, fertilizer industries, terminals and the location where samples were collected.

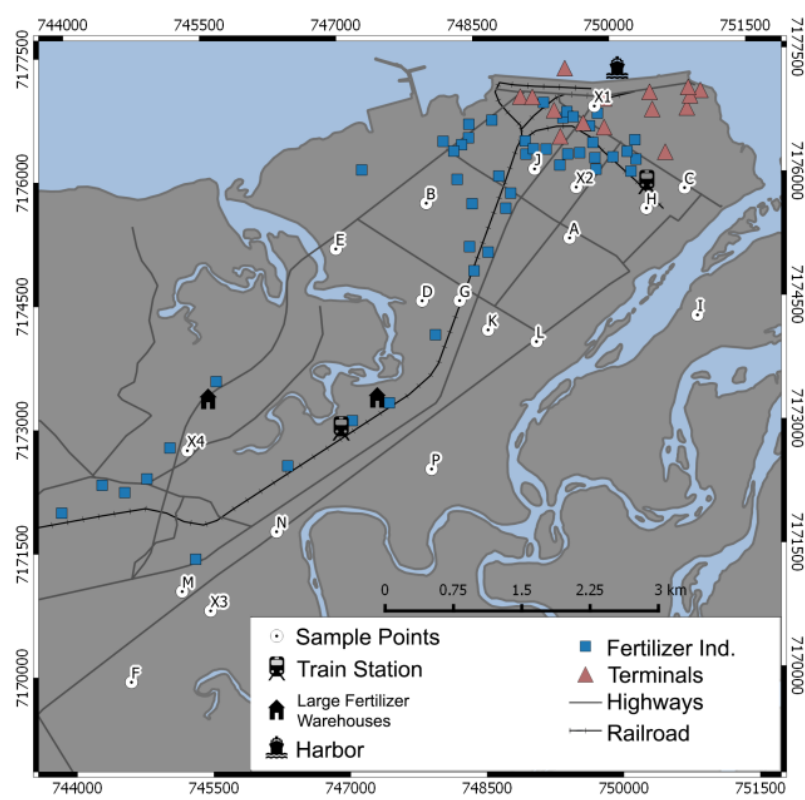

Figure 1. Sample points and location of the potential air pollution emission sources in Paranaguá.
Due to their wide distribution and importance, elementary schools were used as references to determine the sampling areas, 20 sampling points were selected (A-N and $\mathrm{P})$. The $(\mathrm{O})$ sample was lost due to sampling problems (Figure 1). Additional samples were collected in the front of the port (X1); in the center of the port area (X2); in a residential area next to the city access (X3); in the fertilizer industrial area (X4).

Due to its wide use in tropical urban environments, the barks of the tree Terminalia catappa, also know in Brazil as "Sombreiro" (shadow maker), were used as a bioindicator of air pollutants. The samples of the tree barks were collected using an ultrapure titanium knife at a height of 1.5-2.5 $\mathrm{m}$ from the soil. At each sampling site, two bark samples were collected located on different regions of the tree. To minimize the possible effects of variation due to different patterns of accumulation, these barks were mixed into a single sample for analysis. Each sample was stored in a paper bag. Information concerning the sampling site, such as the geographical coordinates and the land use around the sampling site were registered.

The tree barks were cleaned using disposable white dental brushes with nylon soft bristles to remove loosely attached particles, and then, barks were manually ground using a titanium grater until samples of 3-mm thickness were obtained. Each sample was then ground to powder using a vibratory micro mill with an agate mortar (Frisch Pulverisette 0 ). To ensure the homogeneity of the particle sizes, all bark samples were sieved using a 400-mesh sieve. Approximately $0.5 \mathrm{~g}$ of each powdered sample was transformed into $20-\mathrm{mm}$ diameter tablets by applying 15 tons of pressure for 60 s. A duplicate tablet was made for each sampling site.

The content of the prepared sample was measured using an energy dispersive $\mathrm{X}$-ray fluorescence spectrometer (EDX 700-HS, Shimadzu Corporation Analytical Instruments Division, Kyoto, Japan). The instrument employed a low-power Rh-target tube, at a voltage of 5-50 $\mathrm{kV}$ and a current of 1-1000 uA. The characteristic $\mathrm{X}$-ray radiation emitted was detected using a $\mathrm{Si}(\mathrm{Li})$ detector. X-ray fluorescence emission spectra were collected for $240 \mathrm{~s}$ for the elements $\mathrm{Na}-\mathrm{Sc}$ and 400 $\mathrm{s}$ for the elements in the range of $\mathrm{T}-\mathrm{U}$ on a $10 \mathrm{~mm}$ surface area of the samples in a vacuum. Each tree bark sample tablet was analyzed twice. The sample intensities were converted into element 
concentrations ( $\mu \mathrm{g} \mathrm{g}^{-1}$ ) according to fundamental parameter calibrations using the NIST Standard, SRM 1547 Peach Leaves (National Institute of Standards, Gaithersburg, MD, USA). Finally, carbon, in the form of cellulose, was used as the mass balance. The sampling and analysis method was validated by Carneiro et. al. ${ }^{5}$.

A geographic information system was used to spatialize the results obtained using X-ray fluorescence. The method of "Pretty Breaks", traditional in geospatial software and geospatial analysis was used to create a pollutant scale. Using this method, a sequence of equally spaced and rounded values in the range of the values obtained in the samplings is calculated. The values are chosen to be 1,2 or 5 the power of 10 .

\section{Results and discussion}

The levels of the chemical elements in tree bark are shown in Table 1. In order to differentiate the pollutant emission sources in the city the following indicators were used: $\mathrm{Cl}, \mathrm{K}$ and $\mathrm{P}$, as indicators of the manufacture of fertilizers; $\mathrm{Zn}, \mathrm{Al}, \mathrm{Ba}$ and $\mathrm{Mg}$ indicators of traffic ${ }^{5}, 16, \mathrm{~S}$ as heavy oils burn indicator $^{10}$ and $\mathrm{Fe}$ as indicator of railway activity ${ }^{17}$.
Potassium is one of the most used elements for crops fertilization. It is commonly applied in the salt form $\mathrm{KCl}$, the association with $\mathrm{Cl}^{-}$makes the $\mathrm{K}^{+}$less leachable when applied to the soil ${ }^{18}$. The results depicted in Figure 2A shows that $\mathrm{K}$ and $\mathrm{Cl}$ have the same distribution profile, both more abundant in sites next the major fertilizer warehouses (Figure 2A). Crop chemical fertilizers are usually manufactured as a mixture of $\mathrm{K}, \mathrm{N}$ and $\mathrm{P}$ to give the so called NPK fertilizer mixture. The results obtained showed that $\mathrm{P}$ has a less clear distribution than $\mathrm{K}$, however, in one sample, high values of $\mathrm{P}$ were detected near a fertilizer warehouse (Figure 2A).

It was not possible to identify patterns for traffic-related elements ( $\mathrm{Zn}, \mathrm{Al}, \mathrm{Ba}$ and $\mathrm{Mg}$ ), the exception occurred in the sampling point I, which presented low values for all traffic-related elements. This particular sampling site is located on an Island (Ilha dos Valadares) which is a traffic restricted area with access only to emergency vehicles ${ }^{19}$. This data corroborates the use of $\mathrm{Zn}, \mathrm{Al}$, $\mathrm{Ba}$ and $\mathrm{Mg}$ as traffic indicators (Figure 2B).

Table 1. Sample points with coordinates and the results of the elemental tree bark analysis in ppm.

\begin{tabular}{|c|c|c|c|c|c|c|c|c|c|c|c|c|c|c|c|c|c|c|c|c|}
\hline Id & Lat. & Long. & & $\mathrm{Ba}$ & & $\mathrm{Fe}$ & & $\mathrm{Zn}$ & & $\mathrm{Mg}$ & & l & & ? & & & & & & 1 \\
\hline $\bar{A}$ & 749525 & 7175230 & 94.4 & - & 151.7 & - & 32.3 & - & 1840.0 & - & 115.6 & - & 910.0 & - & 1930.0 & - & 1820.0 & - & 855.5 & - \\
\hline B & 747958 & 7175679 & 55.5 & - & 104.7 & - & 28.9 & - & 2050.0 & - & 78.1 & - & 880.0 & - & 1890.0 & - & 2480.0 & - & 1945.6 & - \\
\hline $\mathrm{C}$ & 750800 & 7175816 & 280.7 & - & 353.5 & - & 20.5 & - & 3150.0 & - & 305.5 & - & 810.0 & - & 1880.0 & - & 420.0 & - & 178.0 & - \\
\hline $\mathrm{D}$ & 747891 & 7174497 & 144.8 & +-22.1 & 573.6 & +-87.0 & 26.9 & +-0.8 & 1715.0 & +-106.1 & 141.4 & +-3.5 & 1325.0 & +-35.4 & 1985.0 & +-7.1 & 1430.0 & +-14.1 & 417.8 & +-28.5 \\
\hline $\mathrm{E}$ & 746954 & 7175143 & 330.4 & - & 202.4 & - & 21.0 & - & 2300.0 & - & 168.0 & - & 930.0 & - & 1660.0 & - & 4540.0 & - & 2983.4 & - \\
\hline $\mathrm{F}$ & 744613 & 7169931 & 145.2 & +-55.9 & 184.2 & +-6.4 & 98.8 & +-12.5 & 1440.0 & +-14.1 & 151.0 & +-7.3 & 780.0 & +-0.0 & 1970.0 & +-14.1 & 2165.0 & +-7.1 & 955.2 & +-2.6 \\
\hline G & 748303 & 7174492 & 106.5 & +-39.9 & 291.8 & +-7.1 & 33.9 & +-1.7 & 2090.0 & +-0.0 & 189.1 & +-18.2 & 980.0 & +-28.3 & 2570.0 & +-14.1 & 7365.0 & +-49.5 & 5504.7 & +-72.1 \\
\hline $\mathrm{H}$ & 750376 & 7175575 & 72.3 & +-5.1 & 117.7 & +-15.6 & 20.5 & +-1.0 & 2815.0 & +-21.2 & 97.6 & +-18.8 & 1005.0 & +-35.4 & 1915.0 & +-21.2 & 780.0 & +-28.3 & 188.2 & +-30.5 \\
\hline I & 750913 & 7174270 & 38.5 & +-10.9 & 49.9 & +-5.6 & 13.4 & +-0.9 & 1400.0 & +-14.1 & 43.6 & +-2.4 & 790.0 & +-14.1 & 1655.0 & +-7.1 & 980.0 & +-14.1 & 165.1 & +-42.8 \\
\hline $\mathrm{J}$ & 749156 & 7176074 & 57.4 & +-24.7 & 139.2 & +-3.9 & 41.8 & +-2.9 & 1645.0 & +-21.2 & 143.1 & +-11.9 & 865.0 & +-21.2 & 1765.0 & +-35.4 & 1770.0 & +-84.9 & 1473.1 & +-68.2 \\
\hline $\mathrm{K}$ & 748609 & 7174131 & 103.2 & - & 122.7 & - & 27.5 & - & 1290.0 & - & 89.9 & - & 990.0 & - & 1790.0 & - & 1610.0 & - & 897.0 & - \\
\hline $\mathrm{L}$ & 749138 & 7173980 & 121.3 & - & 228.0 & - & 43.6 & - & 2430.0 & - & 137.2 & - & 950.0 & - & 1860.0 & - & 420.0 & - & 125.8 & - \\
\hline M & 745190 & 7171020 & 22.6 & - & 37.7 & - & 11.5 & - & 1770.0 & - & 41.7 & - & 840.0 & - & 1670.0 & - & 1760.0 & - & 1415.0 & - \\
\hline $\mathrm{N}$ & 746240 & 7171727 & 106.4 & - & 226.2 & - & 36.8 & - & 1910.0 & - & 150.9 & - & 860.0 & - & 1520.0 & - & 1750.0 & - & 1119.1 & - \\
\hline $\mathrm{P}$ & 747957 & 7172455 & 160.3 & +-30.3 & 234.6 & +-0.5 & 25.6 & +-2.6 & 2490.0 & +-56.6 & 179.9 & +-15.9 & 985.0 & +-35.4 & 1825.0 & +-21.2 & 1010.0 & +-42.4 & 168.7 & +-19.0 \\
\hline $\mathrm{X} 1$ & 749827 & 7176824 & 186.0 & +-63.3 & 302.0 & +-37.6 & 28.0 & +-0.8 & 1090.0 & +-14.1 & 180.5 & +-5.4 & 930.0 & +-0.0 & 2495.0 & +-7.1 & 2490.0 & +-14.1 & 1183.1 & +-33.4 \\
\hline $\mathrm{x} 2$ & 749610 & 7175844 & 79.1 & +-9.1 & 101.6 & +-28.5 & 12.0 & +-0.0 & 1250.0 & +-14.1 & 67.9 & +-5.8 & 985.0 & +-7.1 & 1355.0 & +-7.1 & 1430.0 & +-28.3 & 360.5 & +-29.0 \\
\hline $\mathrm{X} 3$ & 745498 & 7170781 & 224.3 & +-222.2 & 71.3 & +-8.0 & 15.9 & +-0.9 & 2330.0 & +-14.1 & 109.9 & +-7.4 & 800.0 & +-14.1 & 1890.0 & +-14.1 & 660.0 & +-14.1 & 206.2 & +-35.4 \\
\hline $\mathrm{X} 4$ & 745278 & 7172728 & 165.7 & - & 240.6 & - & 32.7 & - & 2070.0 & - & 203.0 & - & 1140.0 & - & 2220.0 & - & 7780.0 & - & 5155.6 & - \\
\hline
\end{tabular}



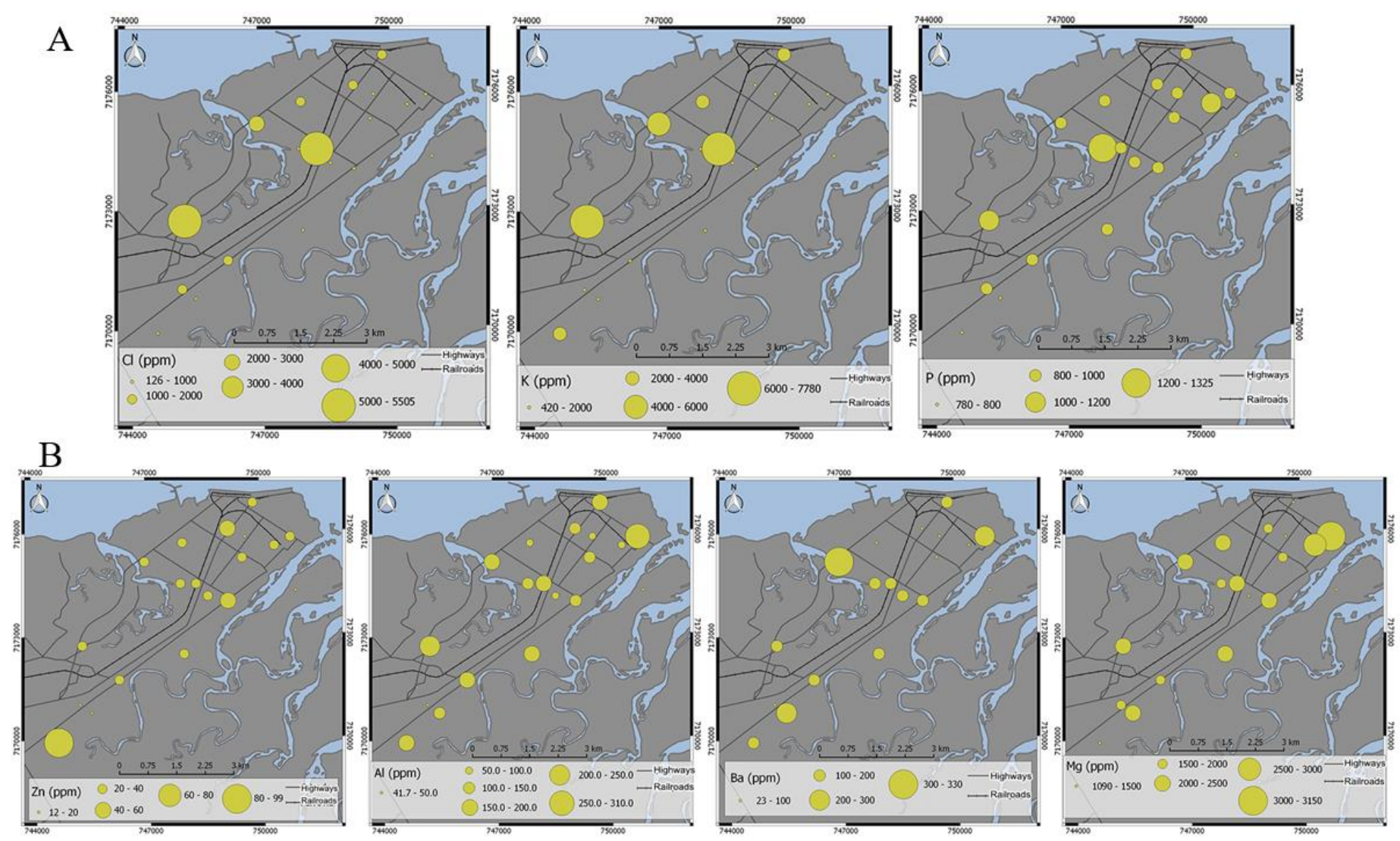

Figure 2. Maps of the analyzed elements according to the classification of probable emission source. (Fertilizers: $\mathrm{Cl}$, $\mathrm{K}$ and P; Traffic: $\mathrm{Zn}, \mathrm{Al}, \mathrm{Ba}$ and $\mathrm{Mg}$ ).

Sulphur is related to crude oil burn; this element is present in naval fuel and in low quality commercial diesel ${ }^{10}$. The distribution of $\mathrm{S}$ indicates that this element is abundant in sites near crossroads of heavy truck traffic and in the sampling site near the port (Figure 3A). Figure 3B

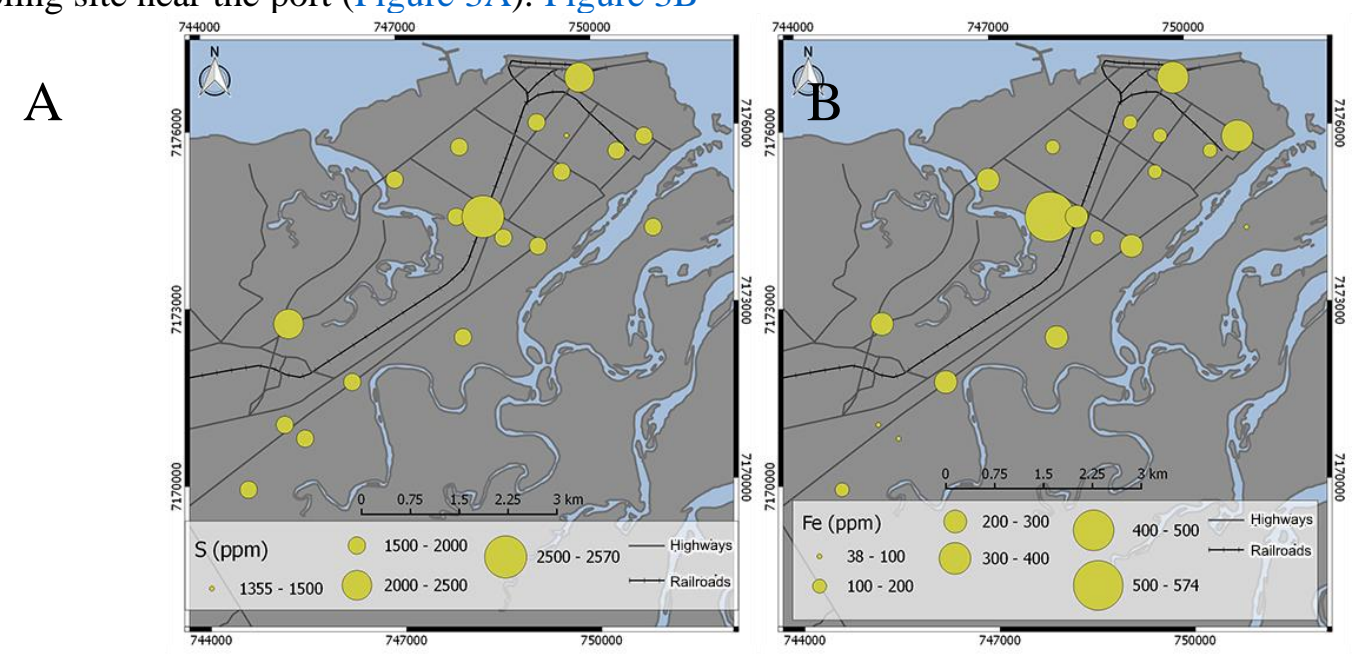

Figure 3. Maps of the analyzed elements according to the classification of probable emission source ( $\mathrm{A}$ - Crude Oil and $\mathrm{B}$ - railroads). shows the distribution of Fe. The higher levels of this element were identified in sampling sites near the railway and train stations, hence, confirming the relationship between Fe levels and railways described in the literature ${ }^{17}$. 


\section{Conclusions}

In this work we investigated the use of tree barks as an atmospheric pollution bioindicator aiming to determine the emission sources in a portuary context. We identified that high levels of $\mathrm{K}$ and $\mathrm{Cl}$ were detected near fertilizer warehouses. Furthermore, high levels of $\mathrm{Fe}$ were detected near railways and train stations. The low levels of the elements $\mathrm{Zn}, \mathrm{Al}, \mathrm{Ba}$ and $\mathrm{Mg}$ detected in a traffic restricted zone confirm the use of these elements as markers of vehicles traffic and validate the approach of using tree barks for air pollution biomonitoring.

\section{Acknowledgments}

This work was funded by the Brazilian Ministry of Science, Technology and Innovation (MCTI), the Coordination for the Improvement of Higher Education Personnel - Brazil (CAPES) and the National Council for Scientific and Technological Development (CNPq).

\section{References}

[1] WHO, 7 million premature deaths annually linked to air pollution, WHO. (2014). http://www.who.int (accessed July 29, 2015).

[2] Bell, M. L., Cifuentes, L.A., Davis, D.L., Cushing, E., Gusman Telles, A., Gouveia, N., Environmental health indicators and a case study of air pollution in Latin American cities, Environmental Research 111 (2011) 57-66. https://doi.org/10.1016/j.envres.2010.10.005.

[3] Romieu, I., Álamo-Hernández, U., TexcalacSangrador, J. L., Pérez, L., Gouveia, N., McConell, R.. A contaminação atmosférica nas Américas: tendências, políticas e efeitos, in: Determinantes Ambientais E Sociais Da Saúde, Opas; Editora Fiocruz, Washington, 2011: pp. 475-495. http://bases.bireme.br/cgi-

bin/wxislind.exe/iah/online/?IsisScript $=\mathrm{iah} / \mathrm{iah}$.xis $\&$ src $=$ google $\&$ base $=$ LILACS \&lang $=$ p \&nextActio $\mathrm{n}=$ lnk\&exprSearch $=756802$ \&indexSearch $=$ ID (accessed October 19, 2015).

[4] Marć, M., Tobiszewski, M., Zabiegała, B., Guardia, M. de la, Namieśnik, J., Current air quality analytics and monitoring: A review,
Analytica Chimica Acta 853 (2015) 116-126. https://doi.org/10.1016/j.aca.2014.10.018.

[5] Carneiro, M.F.H., Ribeiro, F.Q., FernandesFilho, F.N., Lobo, D.J.A., Barbosa Jr., F., Rhoden, C.R., Mauad, T., Saldiva, P. H. N., CarvalhoOliveira, R., Pollen abortion rates, nitrogen dioxide by passive diffusive tubes and bioaccumulation in tree barks are effective in the characterization of air pollution, Environmental and Experimental Botany. $72 \quad$ (2011) 272-277. https://doi.org/10.1016/j.envexpbot.2011.04.001.

[6] Guéguen, F., Stille, P., Millet, M., Air quality assessment by tree bark biomonitoring in urban, industrial and rural environments of the Rhine Valley: PCDD/Fs, PCBs and trace metal evidence, Chemosphere $\quad 85 \quad$ (2011) 195-202. https://doi.org/10.1016/j.chemosphere.2011.06.03 2.

[7] Senhou, A., Chouak, A., Cherkaoui, R., Moutia, Z., Lferde, M., Elyahyaoui, A., Khoukhi, T.E., Bounakhla, M., Embarche, K., Gaudry, A., Ayrault, S., Moskura, M., Sensitivity of biomonitors and local variations of element concentrations in air pollution biomonitoring, Journal of Radioanalytical and Nuclear Chemistry 254 (2002) 343-349. https://doi.org/10.1023/A:1021688203179.

[8] Ferreira, A. B., Santos, J. O., Souza, S. O., Júnior, W. N. S., Alves, J. do P. H., Use of passive biomonitoring to evaluate the environmental impact of emissions from cement industries in Sergipe State, northeast Brazil, Microchemical Journal $\quad 103 \quad$ (2012) 15-20. https://doi.org/10.1016/j.microc.2011.12.008.

[9] Gurgatz, B. M., Carvalho-Oliveira, R., Oliveira, D. C. de, Joucoski, E., Antoniaconi, G., Saldiva, P. H. do N., Reis, R. A., Atmospheric metal pollutants and environmental injustice: A methodological approach to environmental risk analysis using fuzzy logic and tree bark, Ecological Indicators 71 (2016) $428-437$. https://doi.org/10.1016/j.ecolind.2016.07.028.

[10] Bailey, D., Solomon, G., Pollution prevention at ports: clearing the air, Environmental Impact Assessment Review 24 (2004) 749-774. https://doi.org/10.1016/j.eiar.2004.06.005. 
[11] Silverman, D.T., Is diesel exhaust a human lung carcinogen?, Epidemiology. 9 (1998) 4-6. https://www.ncbi.nlm.nih.gov/pubmed/9430259.

[12] Dawson, S. V., Alexeeff, G. V., Multi-Stage Model Estimates of Lung Cancer Risk from Exposure to Diesel Exhaust, Based on a U.S. Railroad Worker Cohort, Risk Analysis 21 (2001) 1-18. https://doi.org/10.1111/0272-4332.211085.

[13] Pandya, R. J., Solomon, G., Kinner, A., Balmes, J. R., Diesel exhaust and asthma: hypotheses and molecular mechanisms of action., Environ Health Perspect. 110 (2002) 103-112. https://www.ncbi.nlm.nih.gov/pubmed/11834468.

[14] Berechman, J., Tseng, P.-H., Estimating the environmental costs of port related emissions: The case of Kaohsiung, Transportation Research Part D: Transport and Environment 17 (2012) 35-38. https://doi.org/10.1016/j.trd.2011.09.009.

[15] Campos Neto, C.A. da S., Pêgo Filho, B., Romminger, A. E., Ferreira, I. M., Portos brasileiros 2009: ranking, área de influência, porte e valor agregado médio dos produtos movimentados, (2009). http://repositorio.ipea.gov.br/handle/11058/2606 (accessed January 13, 2017).

[16] Guéguen, F., Stille, P., Dietze, V., Gieré, R., Chemical and isotopic properties and origin of coarse airborne particles collected by passive samplers in industrial, urban, and rural environments, Atmospheric Environment 62 (2012) 631-645. https://doi.org/10.1016/j.atmosenv.2012.08.044.

[17] Gehrig, R., Hill, M., Lienemann, P., Zwicky, C. N., Bukowiecki, N., Weingartner, E., Baltensperger, U., Buchmann, B., Contribution of railway traffic to local PM10 concentrations in Switzerland, Atmospheric Environment 41 (2007) 923-933.

https://doi.org/10.1016/j.atmosenv.2006.09.021.

[18] Ernani, P. R., Bayer, C., Almeida, J.A. de, Cassol, P. C., Vertical mobility of cations as influenced by the method of potassium chloride application to variable charge soils, Revista Brasileira de Ciência do Solo 31 (2007) 393-401. https://doi.org/10.1590/S0100-

06832007000200022
[19] Toledo, A. do R., Sistema pronominal possessivo em uso na Ilha dos Valadares, (2010). http://dspace.c3sl.ufpr.br:8080/dspace/handle/188 4/24437 (accessed November 20, 2015). 